\title{
Research Article \\ Equation for General Description of Power Behaviour in Fuel Cells
}

\author{
María J. Lavorante $\mathbb{D}^{1},{ }^{1}$ Alfredo R. Sanguinetti, ${ }^{2}$ Héctor J. Fasoli, $^{2}$ and Ricardo M. Aiello ${ }^{1}$ \\ ${ }^{1}$ Departamento de Investigación y Desarrollo en Energías Renovables, del Instituto de Investigaciones Científicas y Técnicas para la \\ Defensa, Juan Bautista de la Salle 4233, B1603ALQ, Villa Martelli, Buenos Aires, Argentina \\ ${ }^{2}$ Facultad de Ingeniería del Ejercito, Escuela Superior Técnica General Manuel Nicolás Savio, Avenida Cabildo 15, C1426AAA, \\ Ciudad Autónoma de Buenos Aires, Buenos Aires, Argentina
}

Correspondence should be addressed to María J. Lavorante; mjlavorante@gmail.com

Received 30 March 2018; Revised 25 September 2018; Accepted 11 October 2018; Published 7 November 2018

Academic Editor: Onder Ozgener

Copyright (C) 2018 María J. Lavorante et al. This is an open access article distributed under the Creative Commons Attribution License, which permits unrestricted use, distribution, and reproduction in any medium, provided the original work is properly cited.

\begin{abstract}
The analytical development of an equation that allows representing the general behavior of electrochemical cells and, in particular, proton exchange membrane fuel cells is presented in this work. The statement from which the proposed equation emerged was made by Rysselberghe where electrolytic cells work as power supply and around which an electrical current moves out of equilibrium. The data used to test the equation were taken from discharged slopes of PEM fuel cells constructed in the Institute of Scientific and Technical Research for the Defense with researchers from the Army Engineering Faculty and from literature. The equation $P_{r}=I_{r}\left(2-I_{r}\right)$ makes it clear that the relative power $\left(P_{r}\right)$ is a quadratic function of the relative current $\left(I_{r}\right)$ and shows a correlation coefficient close to 0.99 with respect to the experimental results of all data analyzed. It is important to remark that the parameters by which the prototypes were constructed were different: the amount and type of catalysts used, the active area, the material of bipolar plates, the type of electrolyte, the number of unit cells, and the different working conditions. In all cases and in spite of all the differences, which are very significant, the parametric equation proposed fits very well.
\end{abstract}

\section{Introduction}

This research work presents and discusses the analytical development of an equation that allows representing the general behavior of electrochemical cells and its direct application. In particular, this work presents examples of proton exchange membrane fuel cells (PEM).

Therefore, the system is described in order to express through a mathematical equation, the behavior of an electrochemical cell that functions as a source of electrical energy. The simplest system consists of two terminal electrodes of electronic conduction immersed in an electrolytic media. The electrodes are frequently metallic, as they are proposed in this analysis, but they may not be. If the electrodes are of different metals, it is convenient to weld one terminal of the same material of one electrode to the other. That has the purpose of measuring the potential difference, in the external circuit, which is the Volta electrical potential. The electrical potential is the necessary work to bring a unit charge from an infinite distance up to the surface of the phase [1]. Figure 1 shows a diagram of this electrochemical cell.

The electrolytic solution provides the media where the reactions, of redox type, take place. The exchange of electric charge involves the electrodes, at least partially. The electrode, where the reduction reaction takes place, receives by convention a positive sign, while the other electrode is assigned a negative sign.

If that electrochemical cell is found out of equilibrium, irreversible phenomena will occur. This fact is evidenced by the appearance of a flow of charges in the external circuit, which is represented by the current density, measured in amps per square centimeters, $\mathrm{i}\left(\mathrm{A} / \mathrm{cm}^{2}\right)$; and the appearance of an electrical potential difference is measured in volts, $E(\mathrm{~V})$. In the case of the current density, the variable measured is the current intensity which is an amps unit, $I(\mathrm{~A})$. The electrical potential is dependent on the current density (quantity and sign of the excess charge) and is denominated as $E(I)$. The 


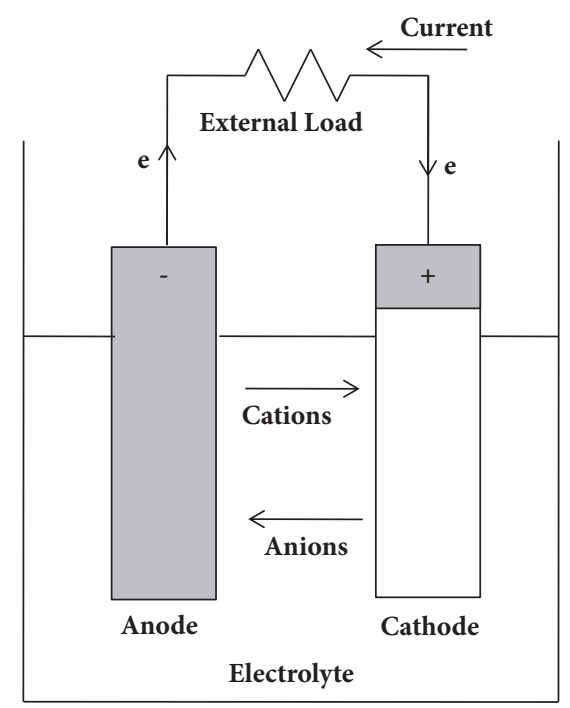

FIGURE 1: Diagram of the simplest electrochemical cell.

potential difference that corresponds to $E(I=0)$ is the potential difference at equilibrium.

The difference between both potentials $(E(I)$ and $E$ $(I=0))$ is denominated as polarization or overpotential, measured in volts, $\eta(\mathrm{V})$. This polarization is associated to the internal heat, which has, Joule, $Q_{i}(J)$ per unit of measure. The current density is $i=I / S$, where $S$ is the surface of the electrodes in square centimeters $\left(\mathrm{cm}^{2}\right)$, establishing that both of them have the same area.

From DeDonder and P. Van Rysselberghe, it can be established that, in a closed system [2],

$$
\eta i=\frac{d Q_{i}}{d t}
$$

Van Rysselberghe introduced a kind of Joule's effect as a consequence of irreversibility. It is produced by the passage of current through the internal resistance, $\mathrm{R}$ (measured in Ohm, $\Omega$ ), between the electrodes of the cell:

$$
R i^{2}=\frac{d Q_{i}}{d t} .
$$

Equaling the equations proposed above, the following is obtained:

$$
\eta i=R i^{2}
$$

Replacing the polarization by its own definition,

$$
E(I) i=E(I=0) i-R i^{2} \text {. }
$$

Defining a geometric element $f=S^{-1}$ and replacing the product of the potential difference multiplied by the current density as useful power of the cell, represented by $P$ and measured in Watt, the following is obtained:

$$
P=E(I=0) I-R I^{2} f \text {. }
$$

The equation expressed above implies that the useful power is a quadratic equation in the current intensity and, according to the assumptions, in (1) and (2) it will be valid for any source of electrochemical energy, coming from galvanic cells.
As far as $E(I=0), R$ and $f$ are constant and the power is a quadratic function of the current intensity obtained by the cell. In the particular case when it is used as a variable of the real current intensity, then the requirement is reduced to $E$ ( $I$ $=0)$ and $R$.

Initially, $E(I=0)$ is assimilated to the reversible Nerst's potential, because it obeys the established condition. Thus, it will be a function of the redox pair, the concentration (the activities of reagents and products of the particular electrochemical reaction), the temperature, and the number of exchange electrons per mol, in the electrochemical reaction.

In the case of fuel cells, the expressions (4) and (5) can be used in a wide range of operations, as long as the supply of fuel and comburent in Nerst's equation, as well as, temperature are ensured. This example is supported by a large body of literature on the subject.

As (5) is a quadratic equation, with constant coefficients, it can be expressed as a function of the maximum values, with the purpose to be independent of the surrounding conditions that determine the corresponding, stationary state.

$P_{M}$ is the maximum power that can be reached when the intensity is $\mathrm{I}_{M}$, if these factors are replaced in (5):

$$
P_{M}=E(I=0) I_{M}-R I_{M}^{2} f .
$$

Just like the useful power the maximum power has, the Watt as unit and the maximum current intensity, the amp, as the current intensity.

Using the properties of the quadratic function the following is obtained:

$$
I_{M}=\frac{E(I=0)}{2 R f}
$$

and

$$
P_{M}=\frac{E^{2}(I=0)}{4 R f} .
$$

Define relative variables like relative power and relative current intensity as $P_{r}=P / P_{M}$ and $I_{r}=I / I_{M}$, respectively. These new, relative variables, as can be observed, are dimensionless.

Replacing these relative variables in (5), the following is obtained:

$$
P_{r} P_{M}=E(I=0) I_{M} I_{r}-R I_{M}^{2} I_{r}^{2} f .
$$

If in the last equation, the relative parameters are replaced, it is simplified and then $I_{r}$ is determined as a common factor, the following is achieved:

$$
P_{r}=I_{r}\left(2-I_{r}\right)
$$

Reorganizing the obtained equation (10), this is obtained:

$$
\frac{P_{r}}{I_{r}}=2-I_{r}
$$

[3].

Equation (10) is equivalent to (5) but in the former, a universal constant appears and it can be valid whatever 
conditions are set, having into account that during all the experiment said conditions have to be constant. To prove its validity and with the purpose of showing a reliable number of samples, the results obtained in different experiments carried out with prototypes developed and built in our laboratory will be exhibited. Data taken from literature were also used.

\section{Materials and Methods}

The construction of the fuel cells is carried out entirely in different departments of the Institute of Scientific and Technical Research Institution for the Defense (CITEDEF Instituto de Investigaciones Científicas y Técnicas para laDefensa) and with researchers from the Army Engineering Faculty (Facultad de Ingenieria del Ejercito, Escuela Superior Tecnica Grl. Manuel N. Savio). The fuel cells are tested with equipment belonging to the latter Institution. The heart of the fuel cells is the membrane electrode assembly (MEA) that consists of the membrane, the catalyst layer and the gas diffusion layer (GDL). The membrane used to construct the MEA is an acid perfluorosulfonic membrane, developed by Dupont, the Nafion ${ }^{\circledR}$. The majority of the prototypes analyzed in this work possess Nafion ${ }^{\circledR} 115$ and the minority Nafion ${ }^{\circledR}$ 117. The catalyst layer is obtained from platinum supported in graphite (EC-20 PTC 20\% Pt, ElectroChemInc). The platinum concentration at the layers that form the MEA is $0.5 \mathrm{mg} / \mathrm{cm}^{2}$. Two different active surface areas were used, in the prototypes analyzed in this work, $16 \mathrm{~cm}^{2}$ and $100 \mathrm{~cm}^{2}$.

With the objective to obtain the maximum hydration grade in the membrane, that is to say, the maximum content of water per sulfonic group, the membrane was conditioned by a chemical and temperature treatment. This treatment consists of several steps [4-7]:

(i) The pieces of membrane were cut in the correct size, depending on the active area.

(ii) The pieces were immersed in a solution of hydrogen peroxide 3\% (Cicarelli, Pro-Analysis) at approximately $90 \circ \mathrm{C}$, during 45 minutes or until the membrane becomes colorless.

(iii) After this step the pieces were washed with distilled water to eliminate the excess of hydrogen peroxide solution and the possible contaminants present.

(iv) The pieces were immersed in a solution of nitric acid $0.5 \mathrm{M}$ (Anedra, Analytical Reactive), during 3 hours at approximately $90 \circ \mathrm{C}$.

(v) Then the pieces were placed in distilled water during 10 minutes to eliminate the excess of acid and then,

(vi) They were immersed in distilled water free of acid at approximately $90 \circ \mathrm{C}$ during 3 hours.

On a 16 or $100 \mathrm{~cm}^{2}$ plate of Toray carbon paper water proofed by polytetrafluoroethylene (PTFE), a paint was applied, consisting of an heterogeneous mixture of carbon black Vulcan (Fuel Cell Earth LLC), dust of polytetrafluoroethylene $(3 \mathrm{M})$, and Conductive Carbon Cement (Leit-C) in a relation between solid of 5/1 in the mixture and with equal parts of isopropyl alcohol (Cicarelli, Pro-Analysis) and ciclohexane (Raudo, Analytical Reactive). The system (mixture) is placed in a mixer mill MM 301 (RetschGmbH) during one hour and a half with agitation of $15 \mathrm{cps}$ to ensure a good dispersion of the solids present. It is named as GDL paint.

When the GDL paint is ready, two consecutive layers of paint are applied on one of the Toray carbon papers, allowing drying of the first layer before the application of the second one. After this operation, the carbon paper is put in a vacuum oven (O.R.L. Hornos Eléctricos) with the purpose of eliminating the rest of the mixture of solvents and then, the temperature is raised to $350^{\circ} \mathrm{C}$, leaving the carbon paper inside the vacuum oven during a period of 30 minutes. The Toray carbon paper is allowed to cool with the purpose of applying a second type of paint, the catalyst paint. This catalyst paint consists of platinum supported on graphite $20 \%$ (EC-20 PTC 20\% Pt, ElectroChemInc), perfluorosulfonic acid-PTFE copolymer 5\% w/w (Alfa Aesar) and isopropyl alcohol in a relation $7 / 1$ weight of disperse solids. This paint is prepared in nitrogen atmosphere and then mixed with a mixer mill MM 301 (RetschGmbH) during 1 hour and a half at $15 \mathrm{cps}$.

The catalyst paint is applied in successive coats (four) allowing drying between applications. This paint is placed on the layers of the GDL paint (which was described above). When the last layer of the catalyst paint is dried, the carbon paper is compressed at $0.1 \mathrm{Ton} / \mathrm{cm}^{2}$ pressure, with a heated press, at $135^{\circ} \mathrm{C}$ during 5 minutes. The selected temperature is the glass transition temperature of the Nafion ${ }^{\circledR}$ polymer. The carbon papers with this treatment, then, are submitted to the following treatment.

The carbon papers are immersed in a nitric acid solution $0.5 \mathrm{M}$ (Anedra, Analytical Reative), during 3 hours at approximately $90^{\circ} \mathrm{C}$. Then the carbon papers are immersed in distilled water during 10 minutes to eliminate the excess of acid. To conclude with the treatment, the carbon papers are immersed in distilled water free of acid at approximately $90^{\circ} \mathrm{C}$ during 3 hours. At that point, the carbon papers are ready for the battery assembly.

The membrane electrode assembly is the part of the fuel cell where the power/energy is produced, and certain types of components are necessary to allow the effective operation of the heart of the cell. These components are the gaskets and the bipolar plates. The gaskets provide a hermetic seal to the MEA with the goal of preventing the fuel and comburent gasses from escaping. The bipolar plates, among other important functions, allow adding unit cells to the stack and provide the channels to address the fuel and comburent. The bipolar plates of the fuel cell developed in our laboratory are made of titanium. These plates are recoated with the layer of gold by physical vapor deposition technique (VPD). The topology that bipolar plates present, in our prototypes, is straightparallel.

\section{Results and Discussion}

With the purpose of verifying the validity of the proposed equation: $P_{r} / I_{r}=2-I_{r}$, a reliable number of samples was analyzed to probe validity but the first samples exposed 
TABLE 1: Construction and operational parameters of fuel cells presented in Figure 2.

\begin{tabular}{lccc}
\hline Fuel Cell & $\mathbf{a}$ & $\mathbf{b}$ & $\mathbf{c}$ \\
\hline Active Area $\left(\mathrm{cm}^{\mathbf{2}}\right)$ & 16 & 16 & 16 \\
Flow field & Straight-Parallel & Straight-Parallel & Straight-Parallel \\
Fuel & Hydrogen & Hydrogen & Hydrogen \\
Oxidant & Oxygen & Oxygen & Oxygen \\
Relative Humidity $(\%)$ & 100 & 100 & 100 \\
Catalyst Load $\left(\mathbf{m g} / \mathbf{c m}^{2}\right)$ & Pt 0.5 & Pt 0.5 & Pt 0.5 \\
Stack power $(\mathbf{W})$ & 17 & 20 & 27 \\
Temperature $\left({ }^{\circ} \mathbf{C}\right)$ & 31 & 27 & 30 \\
Unit cells & 12 & 14 & 18 \\
\hline
\end{tabular}

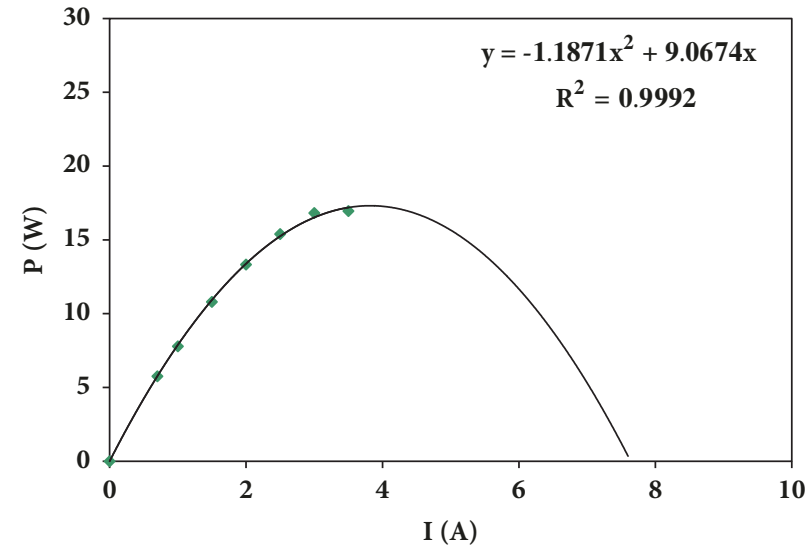

(a)

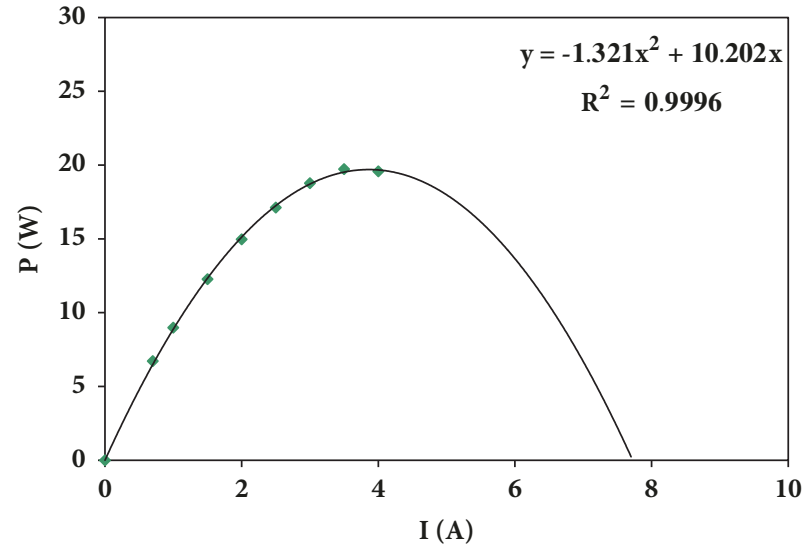

(b)

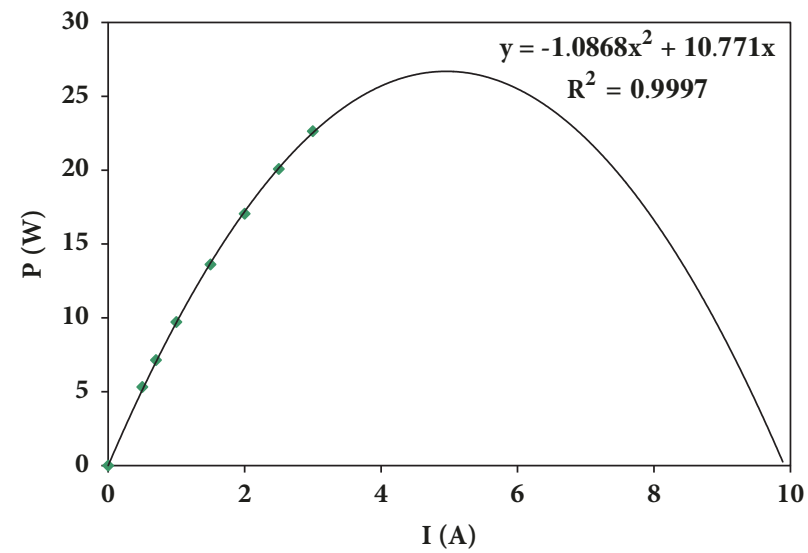

(c)

FIGURE 2: Graphical representation of power as a function of current intensity for fuel cells developed in the laboratory, the active area of which $16 \mathrm{~cm}^{2}$ : (a) of 12; (b) of $14 \mathrm{y}$ (c) of 18 unit cells.

were experiments carried out with fuel cells developed and constructed in the laboratory. The experiments were carried out under different experimental conditions.

Figure 2 shows the graphical representation of power as a function of current intensity of three fuel cells, which have $16 \mathrm{~cm}^{2}$ as active area and a different number of unit cells: 12 , 14 , and 18 elements, respectively. The fuel cell of 12 unit cells presents a maximum power of $17 \mathrm{~W}$ at a working temperature of $31^{\circ} \mathrm{C}$. The fuel cell of 14 unit cells presents a maximum power of $20 \mathrm{~W}$ working at $27^{\circ} \mathrm{C}$ and the last fuel cell analyzed was of 18 unit cells, with a maximum power of $27 \mathrm{~W}$ at $30^{\circ} \mathrm{C}$. Table 1 presents the construction and operational parameters of fuel cells presented in Figure 2.

The graphical representation of power as a function of current intensity arises from the polarization curves obtained connecting the fuel cell to an electronic load (Agilent N3301A System DC Electronic Load, 150 V, 60 A). The electronic load is linked to a PC through an acquisition data program. After 


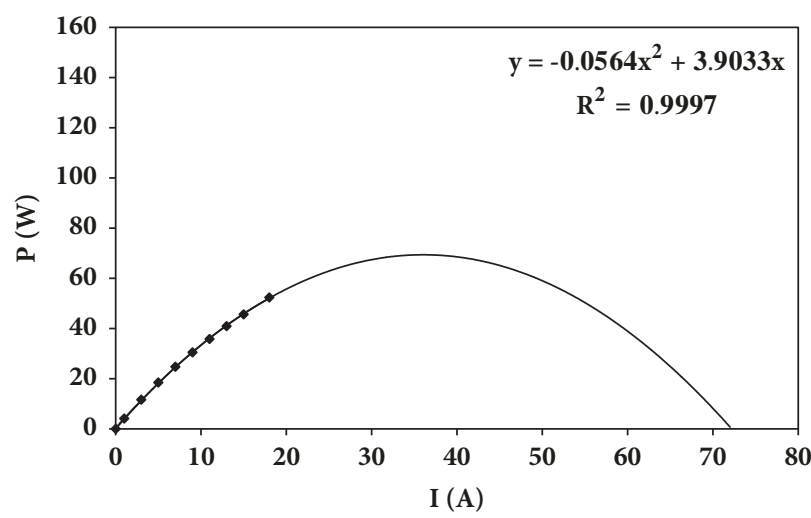

(a)

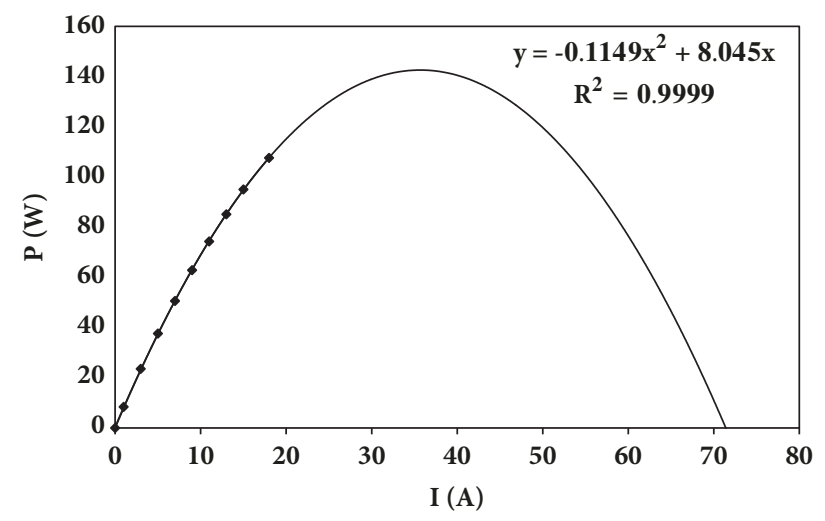

(b)

FIGURE 3: Graphical representation of power as a function of current intensity of fuel cell with an active area of $100 \mathrm{~cm}^{2}$ : (a) of 5 and (b) of 10 unit cells.

the verification of the correct functioning of the fuel cell, the operator establishes the parameters of work as the ranges of current. Once the experiment begins the program varies the current at set intervals of current intensity measured in amps, in a certain period of time (that can be between 30 or 60 seconds). In every value of current that the program stays for that period of time, register ten potential values reach by the fuel cell and makes an average, which is the one that is going to be registered in a table, which is in a spreadsheet. This information allows for representation of the polarization curve of the fuel cell under study. From the values of potential obtained and the current intensity applied, the power is calculated. These experimental values (power and current intensity) fit in a quadratic equation for leastsquare. That equation allows obtaining the coefficient values and the correlation coefficient to the respective square. The program constructs the graphical representation of power as a function of current intensity and sets the equation that best represents the curve obtained. Figures 2 and 3 show the graphical representations obtained by the program.

Figure 3 is the graphical representation of power as a function of the current intensity for two fuel cells of $100 \mathrm{~cm}^{2}$ of surface area with 5 and 10 unit cells. These fuel cells were constructed in our laboratory too. The fuel cells present a maximum potential of $67 \mathrm{~W}$ and $141 \mathrm{~W}$, respectively, working at $31^{\circ} \mathrm{C}$. Table 2 presents the construction and operational parameters of fuel cells represented in Figure 3.

Using the equation that emerges from the graphical representation of power as a function of current intensity, it is possible to calculate the relative power and the relative current intensity. As all the fuel cells respond to expression (10), all the values obtained, regardless of active area, quantity of unit cells, and temperature, can be represented in the same graphic (Figure 4(a)).

All the values that appeared in Figure 4(a) correspond to experimental results whose current intensity, I, is less or equal to the maximum current.

Implementing the least-square method to all the values obtained, it is possible to calculate a straight line very near to the equation proposed, as follows:

$$
y=-(1.067 \pm 0.021) x+(2.038 \pm 0.01)
$$

TABLE 2: Construction and operational parameters of fuel cells presented in Figure 3.

\begin{tabular}{lcc}
\hline Fuel Cell & a & b \\
\hline Active Area $\left(\mathrm{cm}^{\mathbf{2}}\right)$ & 100 & 100 \\
Flow field & Straight-Parallel & Straight-Parallel \\
Fuel & Hydrogen & Hydrogen \\
Oxidant & Oxygen & Oxygen \\
Relative Humidity $(\%)$ & 100 & 100 \\
Catalyst Load $\left(\mathbf{m g} / \mathbf{c m}^{2}\right)$ & Pt 0.5 & Pt 0.5 \\
Stack power $(\mathbf{W})$ & 67 & 141 \\
Temperature $\left({ }^{\circ} \mathbf{C}\right)$ & 31 & 31 \\
Unit cells & 5 & 10 \\
\hline
\end{tabular}

The equation obtained, although through the thermodynamics of irreversible process (10), is no contained inside the error limits calculated by least-squares.

Continuing with the validation of the proposed equation, in this part, data coming from literature were analyzed. From the polarization curves presented in different research articles, the experimental values were estimated. With this information it was possible to reconstruct the graphical representations and the values of Ir and Pr were calculated. For that reason, the values obtained in this way are going to be presented in Appendix A.

Figure 5 presents the results obtained for two different PEM fuel cells: one of $70 \mathrm{~kW}$ and the other of an active area of $52 \mathrm{~cm}^{2}$.

Just to show the different working conditions and components of the fuel cells that we analyzed, a brief commentary of these two fuel cells was made (see Table 3).

In the Netherlands, more precisely at Delfzijl, a $72 \mathrm{~kW}$ pilot PEM Power Plant was installed with the purpose of demonstrating the generation of power with PEM fuel cells in an industrial environment. The hydrogen that feeds the fuel cells is a byproduct of chlorine industry, which is usually disposed of in the form of waste or used for heat production when the neighboring chemical plant cannot use it. Air is 


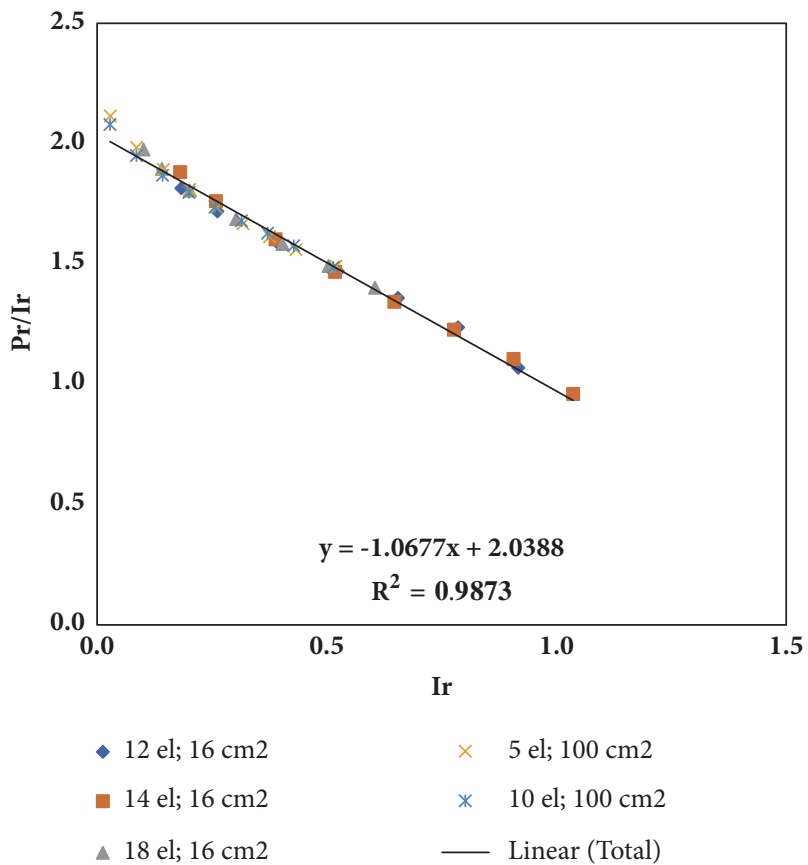

(a)
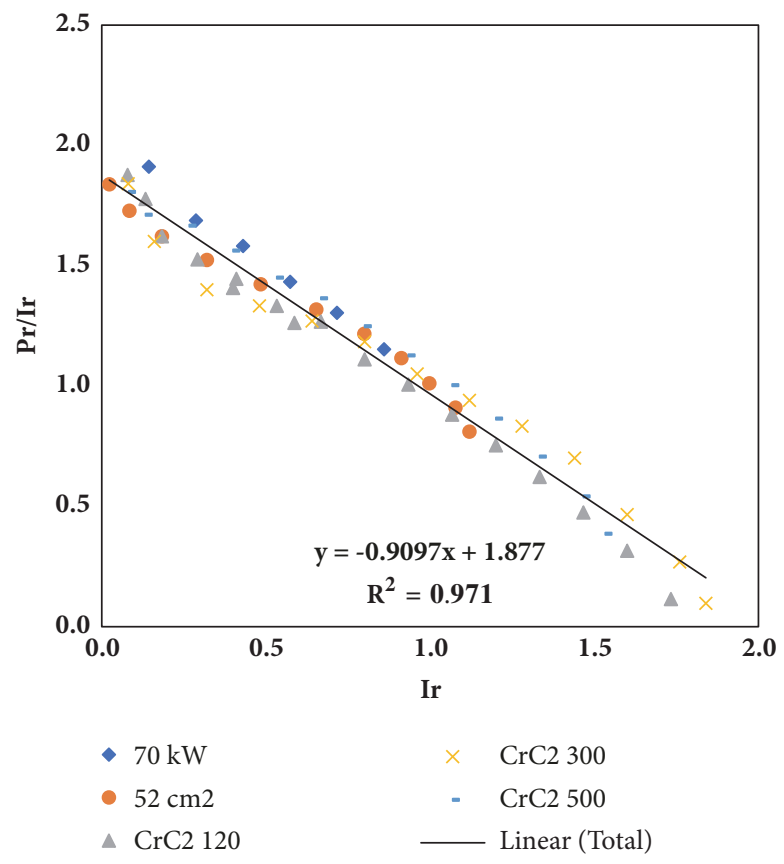

(b)

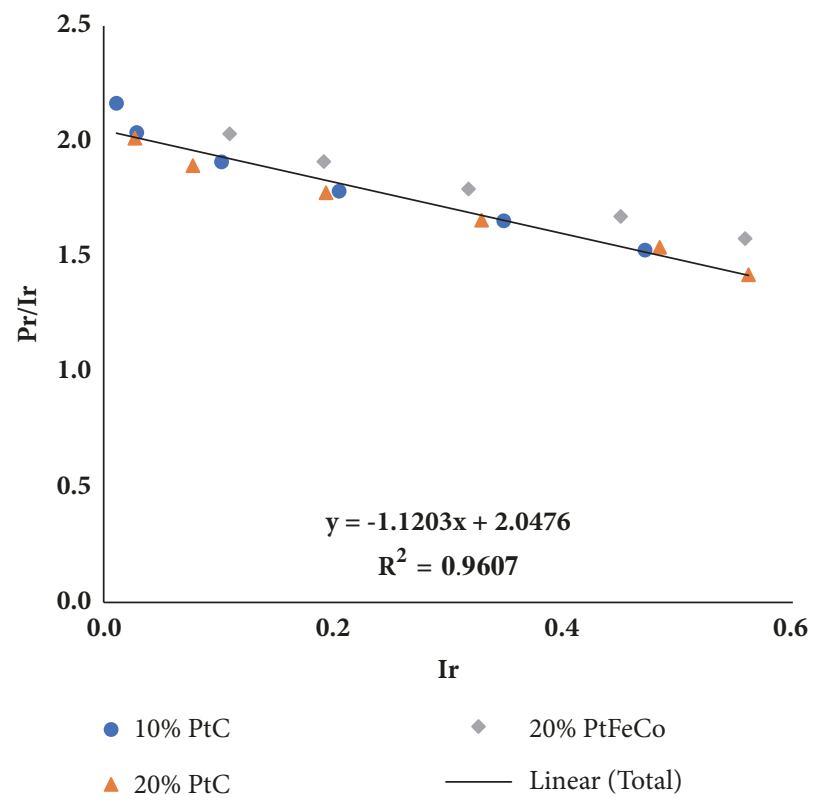

(c)

Figure 4: Graphical representation of the experimental data obtained after the application of the proposal equation for (a) fuel cells constructed in the laboratory, (b) PEM fuel cells taken from literature, and (c) phosphoric acid fuel cell taken from literature.

used as comburent. The plant consists of 12 fuel cell stacks of 75 unit cells. The bipolar plates were made of graphite composite material cooled by a flow of demineralized water. The active area of the electrodes is $200 \mathrm{~cm}^{2}$. The working average temperature of the stacks is $65^{\circ} \mathrm{C}$, hydrogen inlet pressure is about $15 \mathrm{kPa}$ above atmospheric pressure and air is about $10 \mathrm{kPa}$. A packed column is used to humidify the hydrogen and the air at $60^{\circ} \mathrm{C}$, with demineralized water, previous scrubbing. At working temperature, the relative humidity of both gases is $80 \%$ [8].
In the investigation work of Wang et al., the effects of different operation parameters were tested using a PEM fuel cell with an active area of $52 \mathrm{~cm}^{2}$. The membrane electrode assembly consists of Nafion ${ }^{\circledR} 115$ membrane and the electrodes had a platinum loading of $0.4 \mathrm{mg} / \mathrm{cm}^{2}$. Carbon fiber cloth was used as gas diffusion layers and graphite was the material for the bipolar plates with serpentine gas channels. Two gold-plated copper plates pressed the membrane electrode assembly which is positioned between 


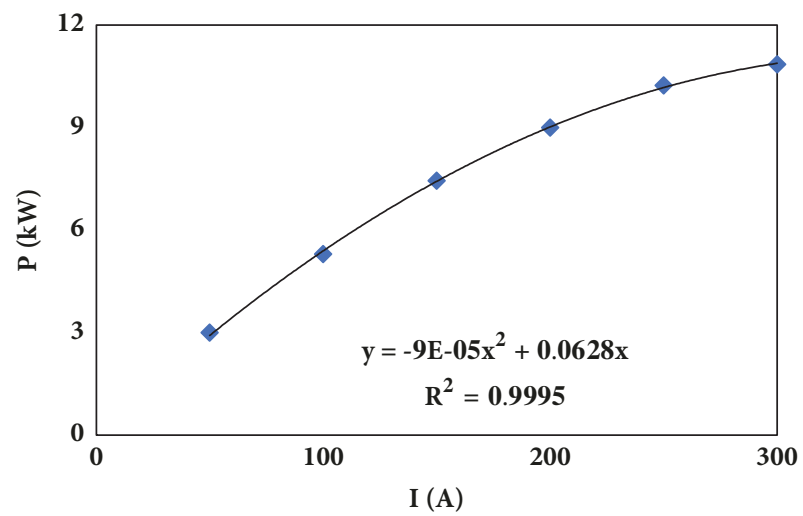

(a)

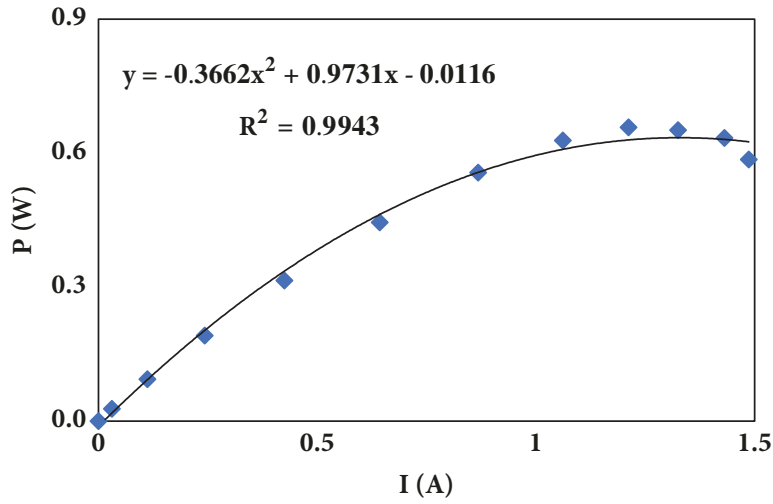

(b)

FIGURE 5: Graphical representation of power as a function of current intensity of two different PEM fuel cells (a) of $70 \mathrm{~kW}$ and (b) of $52 \mathrm{~cm}{ }^{2}$ of active area.

TABLE 3: Construction and operational parameters of fuel cells presented in Figure 5.

\begin{tabular}{lcc}
\hline Fuel Cell & a & b \\
\hline Active Area $\left(\mathrm{cm}^{2}\right)$ & 200 & 52 \\
Bipolar plates & - & Serpentine \\
Bipolar plates materials & Graphite composite & Gold-plated copper \\
Fuel & Hydrogen & Hydrogen \\
Oxidant & Air & Air \\
Relative Humidity $(\%)$ & 80 & - \\
Catalyst Load $\left(\mathbf{m g} / \mathrm{cm}^{2}\right)$ & - & Pt 0.4 \\
Stack power $(\mathbf{k W})$ & 70 & - \\
Temperature $\left({ }^{\circ} \mathbf{C}\right)$ & 60 & - \\
Unit cells & 75 & 1 \\
\hline
\end{tabular}

the bipolar plates. Pure hydrogen and air were used as fuel and comburent, respectively [9].

Tawfik et al. developed a carbide-based amorphous metallic coating alloy by densification applied on an aluminum bipolar plate. The bipolar plates were tested in a single cell with $6.25 \mathrm{~cm}^{2}$ active area at $70^{\circ} \mathrm{C}$. The working pressure of hydrogen and oxygen is $10 \mathrm{psi}$ and the relative humidity is $77 \%$. The power curves obtained during 1000 hours of operation of three different carbide-based coating were analyzed, identified as $\mathrm{CrC}_{2}-120, \mathrm{CrC}_{2}-300$, and $\mathrm{CrC}_{2}$-500. These coatings showed excellent durability for harsh corrosive environment and $22 \%$ savings in hydrogen consumption. Figure 6 is the graphical representation of the values obtained from the polarization curves presented in Tawfik's research work [10]. Table 4 presents the construction and operational parameters of the fuel cells represented in Figure 6.

Figure 4(b) shows the graphical representation of the values obtained for relative power and relative current intensity for the different PEM fuel cells, taken from the literature, described and analyzed above, using (10).

That representation shows that independently of the types of components such as concentration of catalysts, electrolyte,
TABLE 4: Construction and operational parameters of fuel cells presented in Figure 6.

\begin{tabular}{lc}
\hline Fuel Cell & a-b-c \\
\hline Active Area $\left(\mathrm{cm}^{2}\right)$ & 6.25 \\
Bipolar plates materials & Carbide-based coating on Al plate \\
Fuel & Hydrogen \\
Oxidant & Oxygen \\
Relative Humidity $(\%)$ & 77 \\
Temperature $\left({ }^{\circ} \mathrm{C}\right)$ & 70 \\
Unit cells & 1 \\
\hline
\end{tabular}

material of the bipolar plate and number of unit cells, and the working conditions as temperature, flow of fuel and comburent, relative humidity of the gases, active area, and others, all together, can be represented in the same graphic.

To finish the analysis of the equation proposed, the results obtained for a phosphoric acid fuel cell (PAFC) will be presented. Different types of cathode catalysts were studied to show the wide spectrum where this equation can be applied.

Yang et al. presented the polarization curves obtained with different types of cathode catalysts to be used in phosphoric acid fuel cell: $10 \mathrm{wt} \% \mathrm{Pt} / \mathrm{C}, 20 \mathrm{wt} \% \mathrm{Pt} / \mathrm{C}$, and 20 wt \% Pt-alloy (Pt-Fe-Co). The results showed that the alloy catalysts provide $60 \%$ increase in current density if it is compared with the catalyst of pure Pt. These catalysts were tested in a single cell which has an anode with $10 \mathrm{wt}$ $\% \mathrm{Pt} / \mathrm{C}$ at $185^{\circ} \mathrm{C}$. These polarization curves were analyzed and the results were shown in Figure 7 [11]. Table 5 shows the construction and operational parameters of the fuel cells presented in Figure 7.

Figure 4(c) is the result obtained for relative power and current intensity applying equation (10). As can be seen the phosphoric acid fuel cells behaved in the same way as PEM fuel cells with respect to this equation.

In Figure 8(a), all the prototypes were introduced in the same graphic to show that independently of the characteristic 


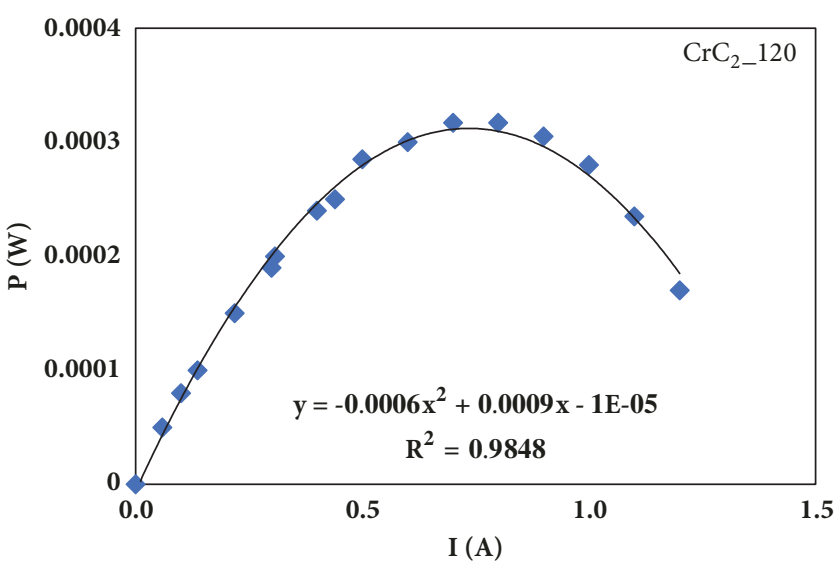

(a)

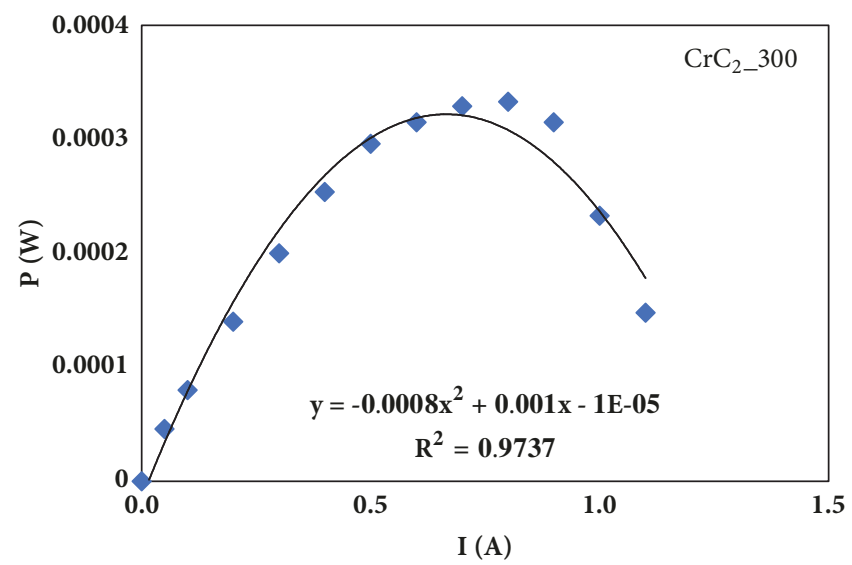

(b)

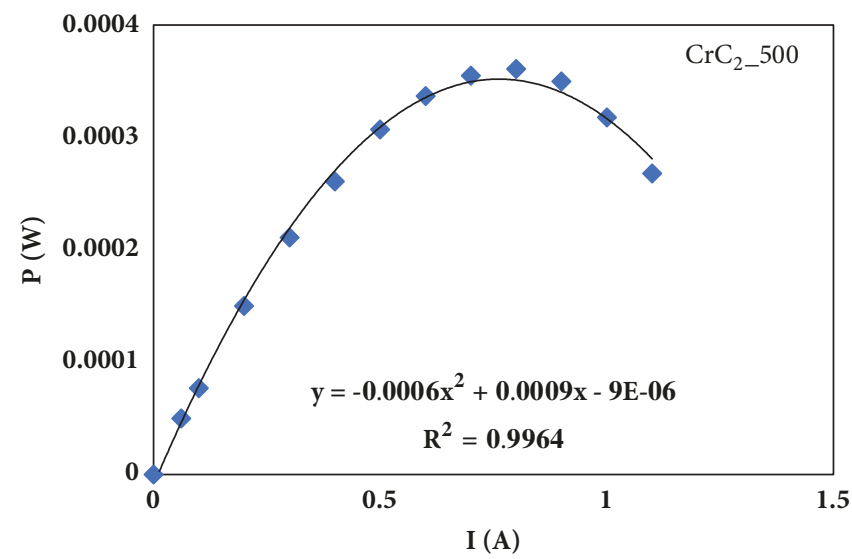

(c)

FIGURE 6: Graphical representation of power as a function of current intensity of different carbide-based amorphous metallic coating: (a) $\mathrm{CrC}_{2}-120$, (b) $\mathrm{CrC}_{2} \_300$, and (c) $\mathrm{CrC}_{2}-500$.

TABLE 5: Construction and operational parameters of fuel cells presented in Figure 7.

\begin{tabular}{lc}
\hline Fuel Cell & a-b-c \\
\hline Anode materials & $10 \% \mathrm{wt} \mathrm{Pt} / \mathrm{C}$ \\
Temperature $\left({ }^{\circ} \mathrm{C}\right)$ & 185 \\
Unit cells & 1 \\
\hline
\end{tabular}

of the fuel cell, in relation with components and independently of the working conditions, the same equation can be followed.

Finally and with the purpose of deciding if the experimental results obtained correspond to values that can be calculated with the equation obtained by thermodynamics of irreversible process, a graphical representation is performed. This representation includes the experimental results of $\mathrm{Pr} / \mathrm{Ir}$ for every Ir as a function of the values that can be obtained by (10). The results were shown in Figure 8(b).

The pairs of values are correlated due to the relation coefficient being higher than 0.99 . The experimental values are the same as the ones obtained by (10), because the representation is a straight line which has a slope that differs very little from the unit.

\section{Conclusions}

In this research work we presented the results obtained with two different kinds of fuel cells (PEM and PAFC), and it is important to remark that the parameters by which these prototypes were constructed were radically different. This implies not only the amount of catalysts and types used in the electrodes, but also the active area, the material of the bipolar plates, the type of electrolyte, the number of unit cells, only to name some of them. Apart from that, different working conditions need to be taken into account, such as flow of comburent and fuel and relative humidity of gases and temperature, again to name only some of them. In all cases and in spite of all the differences pointed out before, which are very relevant, the parametric equation proposed fits very well. It is very important to point out that the statistics applied to the data shows that the constants obtained slightly differ from the universal constant expected.

Equation (9) is the predecessor of (10) and this equation also fits well including very important details, such as 


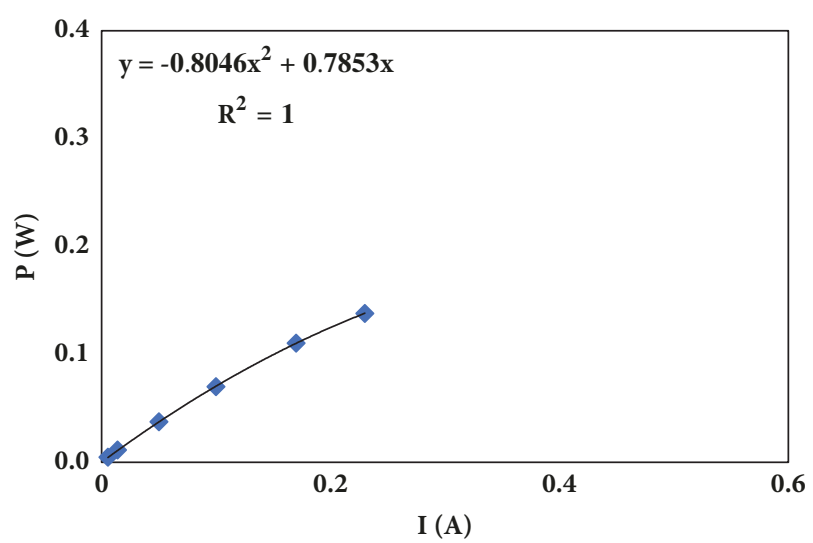

(a)

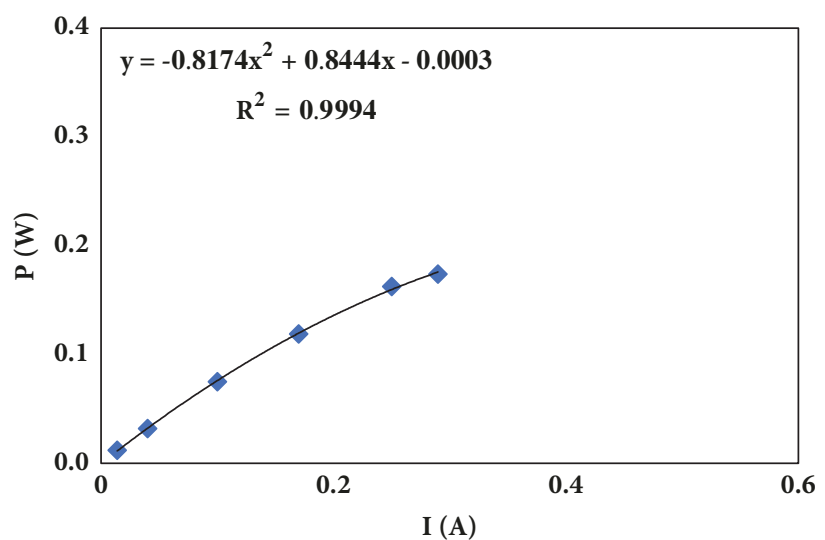

(b)

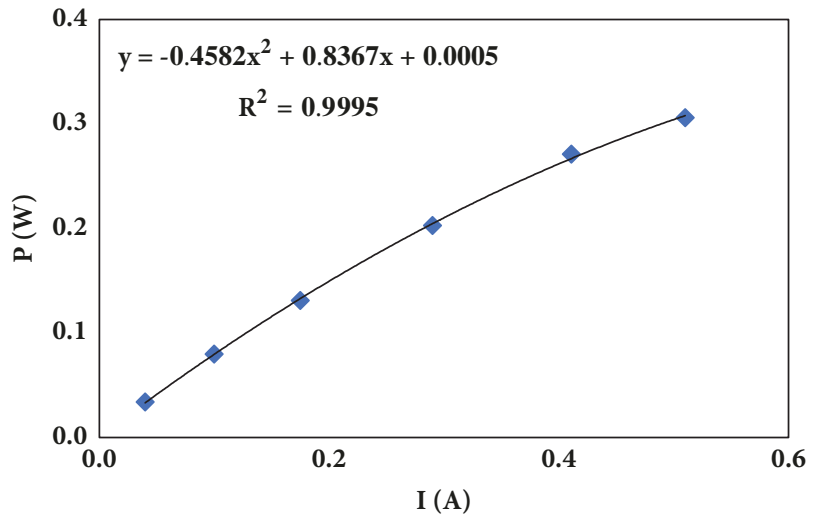

(c)

FIGURE 7: Graphical representation of power as a function of current intensity for three different cathodes of a PAFC (a) $10 \mathrm{wt} \% \mathrm{Pt} / \mathrm{C}$, (b) 20 wt \% Pt/C, and (c) 20 wt \% Pt-alloy (Pt-Fe-Co).

(a) As it can be seen, it is a quadratic equation of constant coefficients where the independent coefficient must be canceled due to the fact that the power in those conditions, $\mathrm{I}=0$, is null.

(b) In many cases, the best equation chosen for the fitting experimental data program produces a quadratic equation of two terms but even in the situations where it is necessary to introduce the value of a third term; these values approach cero.

(c) The sign of the equation appears in the same order as it was proposed.

(d) A mathematical analysis of the equation shows that the inverted parabola must be symmetrical around the axis of intensity of maximum power.

Some of the studied cases used semi empirical equation (modelyzations) to fit the experimental values. The values obtained by those data also aligned to the parametric equation $\mathrm{Pr} / \mathrm{Ir}$ versus Ir, but the coefficients differ from the expected values. Equation (8) in those cases is not asymmetrical parabola around the axis of intensity corresponding to the maximum power. So the real experimental values fit perfectly the equation proposed although the data taken from the graphical representation where semiempirical equations are formulated do not fit in the same way $[12,13]$.

Work is needed along that line to determine the cause of such behavior.

\section{Data Availability}

The validation of the proposed equation and data coming from bibliography were analyzed. From the polarization curves presented in different research articles, the experimental values were estimated. This information allowed for reconstruction of the graphical representations and calculation of the values for Ir and Pr. The values obtained in this way will be presented in appendix $\mathrm{A}$.

\section{Disclosure}

The manuscript is based on the poster that has been presented at the Fuel Cells Science and Technology 2016: A Grove Fuel Cell Event, Glasgow, United Kingdom, the 13th and 14th April, 2016.

\section{Conflicts of Interest}

The authors declare that they have no conflicts of interest. 


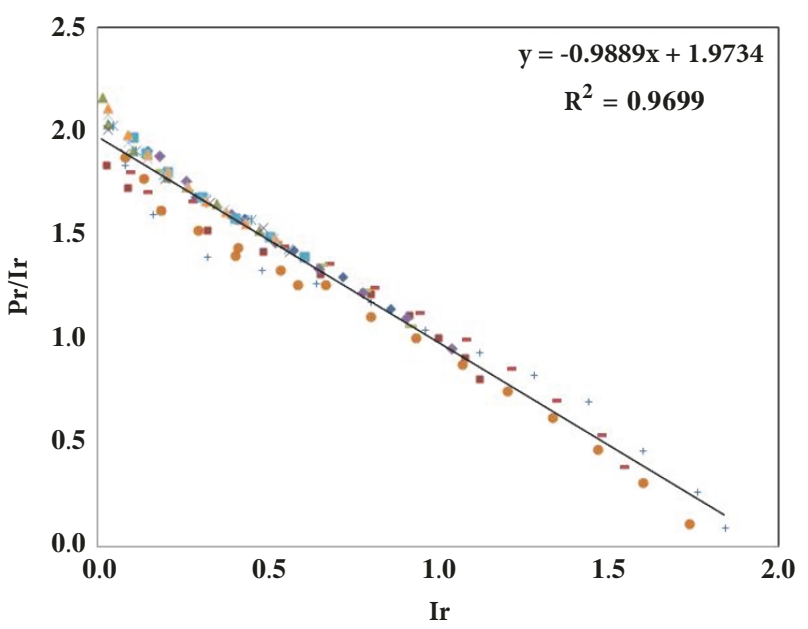

- $70 \mathrm{~kW}$

- $52 \mathrm{~cm} 2$

4 $10 \mathrm{Pt} / \mathrm{C}$

$\times 20 \mathrm{Pt} / \mathrm{C}$

* $20 \mathrm{Pt}-\mathrm{Fe}-\mathrm{Co}$

- $\mathrm{CrC} 2 \_120$

$+\mathrm{CrC} 2300$

- CrC2_500

- 12 el., $16 \mathrm{~cm} 2$

- 14 el., $16 \mathrm{~cm} 2$

- 18 el., $16 \mathrm{~cm} 2$

$\triangle 5 \mathrm{el} ., 100 \mathrm{~cm} 2$

10 el., $100 \mathrm{~cm} 2$

(a)

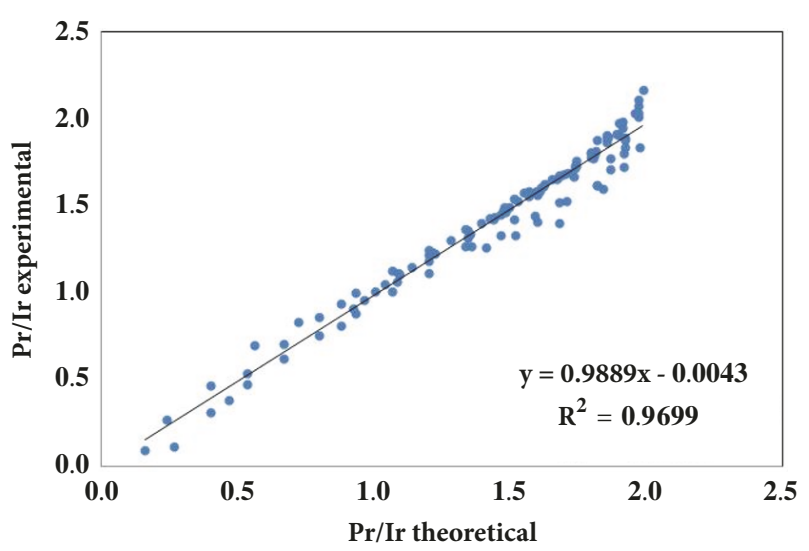

(b)

Figure 8: (a) Representation of all the prototypes analyzed and (b) experimental results as a function of theoretical results of the quotient between relative power and relative current intensity.

\section{Acknowledgments}

This work is dedicated to the memory of the authors' beloved mentor Dr. Juan Isidro Franco (12-09-1945 -13-07-2017), who saw some of them taking their first steps in research, guided them, and was always on their side along the busy road. He dedicated the last years of his life to the development of the work presented here and his passion for his work was transmitted in such a way that he involved them to work side by side on this topic and today they can present it to those researchers interested in it. The authors will miss their conversations on science and life very much. Authors want to thank the Army Project Direction (DIEJ) for the given support. The authors received funding from Argentinean Defense Ministry: PIDDEF 21/11 and 22/11.

\section{Supplementary Materials}

For the validation of the proposed equation, data coming from literature were analyzed. From the polarization curves presented in different research articles, the experimental values were estimated. This information allowed for reconstruction of the graphical representations and calculation of the values for Ir and Pr. The values obtained in this way will be presented in appendix A. (Supplementary Materials)

\section{References}

[1] G. Kortüm, Treatise on Electrochemistry, Elsevier Publishing Company, Amsterdan, Netherlands, 2nd edition, 1965.

[2] J. Brenet, "Énergétique des générateurs électrochimiques," Technique et Documentation - Lavoisier, Paris, 1987.

[3] M. J. Lavorante, L. Gurevich Messina, J. I. Franco, and P. Bonelli, "Design of an integrated power system using a proton exchange membrane fuel cell," International Journal of Hydrogen Energy, vol. 39, no. 16, pp. 8631-8634, 2014.

[4] M. J. Lavorante, B. Scalise, C. J. López, A. R. Sanguinetti, J. I. Franco, and H. J. Fasoli, "Estudio sobre la hidratación de las membranas Nafion ${ }^{\circledR} 117$ a diferentes concentraciones de ácido sulfúrico," http://www.cab.cnea.gov.ar/ieds/images/2009/ hyfusen_2009/trabajos/06-129.pdf, 2009 (accessed 23.03.2018).

[5] Q. Duan, H. Wang, and J. Benziger, "Transport of liquid water through Nafion membranes," Journal of Membrane Science, vol. 392-393, pp. 88-94, 2012.

[6] D. Aili, M. K. Hansen, C. Pan et al., "Phosphoric acid doped membranes based on Nafion ${ }^{\circledR}, \mathrm{PBI}$ and their blends Membrane preparation, characterization and steam electrolysis testing," International Journal of Hydrogen Energy, vol. 36, no. 12, pp. 6985-6993, 2011.

[7] L. Napoli, M. J. Lavorante, J. Franco, A. Sanguinetti, and H. Fasoli, "Effects on nafion ${ }^{\circledR} 117$ membrane using different strong acids in various concentrations," Journal of New Materials for Electrochemical Systems, vol. 16, no. 3, pp. 151-156, 2013.

[8] A. J. Verhage, J. F. Coolegem, M. J. Mulder, M. H. Yildirim, and F. A. de Bruijn, " 30,000 h operation of a $70 \mathrm{~kW}$ stationary PEM fuel cell system using hydrogen from a chlorine factory," International Journal of Hydrogen Energy, vol. 38, no. 11, pp. 4714-4724, 2013.

[9] L. Wang, A. Husar, T. Zhou, and H. Liu, "A parametric study of PEM fuel cell performances," International Journal of Hydrogen Energy, vol. 28, no. 11, pp. 1263-1272, 2003.

[10] H. Tawfik, Y. Hung, and D. Mahajan, "Metal bipolar plates for PEM fuel cell-A review," Journal of Power Sources, vol. 163, no. 2, pp. 755-767, 2007.

[11] J. Yang, Y. Park, S. Seo, H. Lee, and J. Noh, "Development of a 50 kW PAFC power generation system," Journal of Power Sources, vol. 106, no. 1-2, pp. 68-75, 2002. 
[12] J. Kim, S.-M. Lee, S. Srinivasan, and C. E. Chamberlin, "Modeling of proton exchange membrane fuel cell performance with an empirical equation," Journal of The Electrochemical Society, vol. 142, no. 8, pp. 2670-2674, 1995.

[13] M. Miansari, K. Sedighi, M. Amidpour, E. Alizadeh, and M. O. Miansari, "Experimental and thermodynamic approach on proton exchange membrane fuel cell performance," Journal of Power Sources, vol. 190, no. 2, pp. 356-361, 2009. 

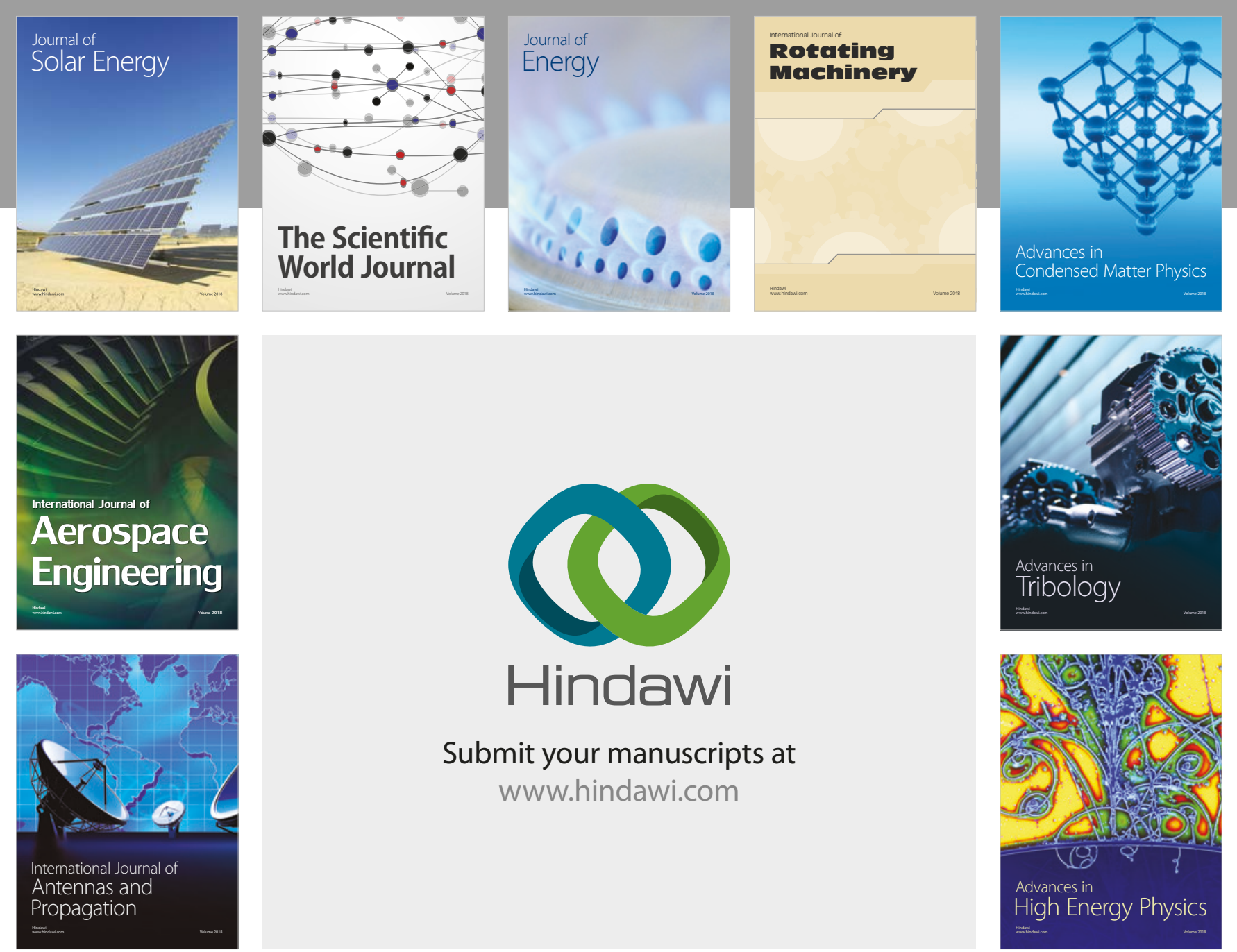

Submit your manuscripts at

www.hindawi.com
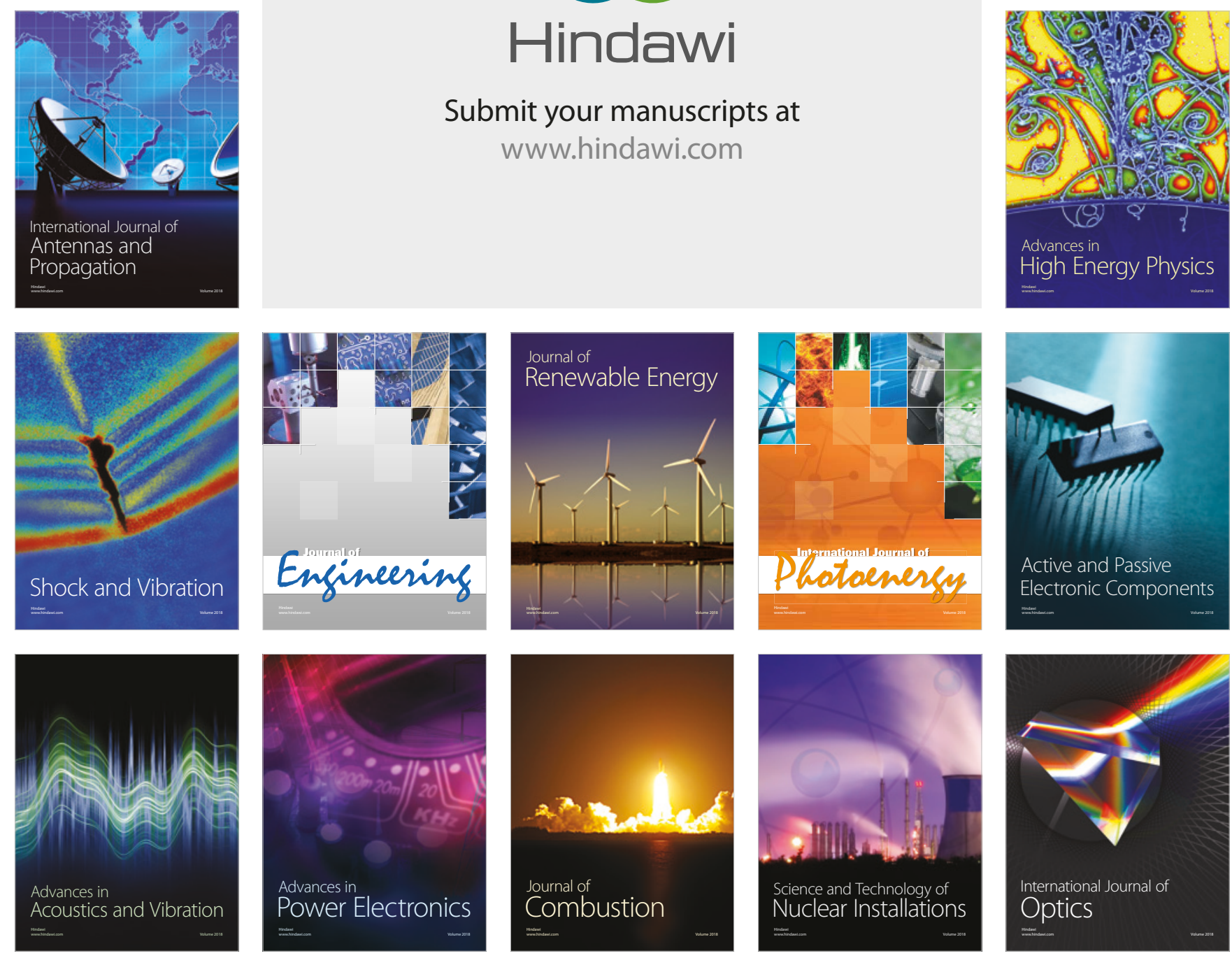